\title{
Kako natančna je lahko transkripcija ${ }^{1}$
}

\author{
Mira Krajnc IviČ \\ Univerza v Mariboru, Filozofska fakulteta, Koroška cesta 160, SI- 2000 Maribor, \\ mira.krajnc@uni-mb.si
}

\section{SCN III/1 [2010], 159-192}

\begin{abstract}
Prispevek skuša pokazati na moč sporočenega kot posledico prepletenosti jezikovnega in nejezikovnega zlasti v neposrednih govorjenih dvogovorih in na pri transkribiranju teh dvogovorov nastale raziskovalčeve težave kot posledice težnje po popolnosti zapisa, saj naj bi popolna, teoretično nenevtralna transkripcija omogočila uporabo deloma analiziranega gradiva za namene različnih opazovanj istega gradiva.
\end{abstract}

The article attempts to show how a message of a direct dialogue gets its (illocutionary) force as the result of the interplay of linguistic, semi-linguistic and non-linguistic activities of the participant. It is also trying to show that researchers' difficulties are the consequences of his or her wish to transcribe a dialogue perfectly, because only a perfect and theoretically non-neutral transcription can be used for several different purposes.

Ključne besede: diskurz, dvogovor, neposredni dvogovor, transkripcija, prozodija

Keywords: discourse, conversation, direct dialogue, transcription, prosody

$1 \mathrm{Z}$ vidika konverzacijske analize se na naslovno vprašanje - kako natančna je lahko transkripcija - pričakuje odgovor, ki bi potrdil, da je transkripcija natančna. To se pravzaprav pričakuje tudi s strani jezikoslovcev, prepričanih, da z jezikom lahko povemo vse, o čemer pa dvomi že npr. Ducrot (1988: 134). Če pomislimo na umetnostna besedila, potem se nemara zdi, da lahko ubesedimo, zapišemo vse. Vendar si tudi pri umetnostnih besedilih s pomočjo zapisanega

\footnotetext{
${ }^{1}$ Prispevek je nastal v okviru raziskovalnega projekta J6-2238 z naslovom Slovenski jezik v stiku evropskega podonavskega in alpskega prostora, ki ga financira Agencija za raziskovalno dejavnost RS; odgovorni nosilec projekta je red. prof. dr. Marko Jesenšek.
} 
in svojih izkušenj ustvarjamo svoje predstave. $\mathrm{K}$ besedilnemu tipu informacij dodajamo okoliščinske, kot si jih predstavljamo, da naj bi bile podane glede na socialne, kulturne in tudi naše individualne izkušnje, ki bi bile po naši presoji skladne z našimi modeli ali vzorci, značilnimi za določen komunikacijski stik. Prav tu se lahko izrazi dvom o resnični natančnosti transkripcije.

2 »Kako govorimo - in potem takem tudi, kako to zapišemo (dodala MKI) -, ni toliko odvisno od družbenega položaja samega, ampak od naše individualne interpretacije ali našega vzorca tega položaja.« (van Dijk 2002: 214). Zapis, tj. reprodukcijo/poustvaritev, prej posnetega govorjenega komunikacijskega stika imenujemo transkripcija. »Transkripcija je neprecenljiva pridobitev v analizi dvogovora, vendar ni nikoli teoretsko nevtralna.« (Edwards 2001: 344). Tako so npr. narečni dvogovori transkribirani fonetično. Ta način transkripcije se uporablja pri zapisovanju neknjižnih zvrsteh jezika. To bi za slovenščino pomenilo, da je tako rekoč vse ožjeinteresne in tiste širšeinteresne dvogovore, v katerih se približevanje neknjižnim zvrstem zdi potrebni pogoj za pritegnitev naslovnika, smiselno zapisovati fonetično. Kaj pa berljivost, dosegljivost, primerljivost tako zbranega gradiva? ${ }^{2}$ Npr. M. Stubbs (1983: 228-229) se zavzema, da transkripcija naj ne bi vsebovala preveč podatkov, saj je po njegovem razumevanje proces izbiranja vzorcev, $v$ katerem nekatere fonetične podrobnosti niso bistvenega pomena, po drugi strani pa trdi, da ne obstaja ena sama pravilna transkripcija danega izreka, zaradi česar se je pomembno naučiti opazovati vedenja, ki jih med samim pogovarjanjem večinoma vzamemo kot dana (Stubbs 1983: 240). Lahko bi rekli, da se Stubbs zavzema za način zapisovanje dvogovorov, kot sicer zapisujemo zapisana sporočila. Za O. Müllerovo (1979: 16) se tako stališče o interpunkciji in rabi ločil pri transkripciji, ne zdi utemeljeno, saj interpunkcija

\footnotetext{
${ }^{2}$ Glej tudi Zemljarič Miklavčič 2008: 92-141. Avtorico v poglavjih Označevanje in transkribiranje govorjenih besedil in Predlog priporočil za transkribiranje besedil $v$ govorni korpus problem transkribiranja zanima zlasti z vidika gradnje korpusa govorjenega jezika. Kot temeljno enoto razume izjavo, ki je omejena s premorom in/ali menjavo govorcev (Zemljarič Miklavčič 2008: 132). Poimenovanje izjava nadomešča poimenovanje vloga, kot jo razume S. Kranjc (Kranjc 1997: 314), in je ne gre zamenjati s terminom izrek kot povedjo v okoliščinah konkretnega komunikacijskega stika. Izrek (angl. utterance) je neločljivo kontekstualizirana enota jezika v rabi, kamor sodijo torej tudi soudeleženčevi signali, npr. členki, medmeti in kratki izreki ( $j a, m h m$, drži, točno, saj vem, ja prav, ravno to, no ja, ne vem itd.), med nejezikovnimi sredstvi pa se v tej funkciji pogosto uporabljajo geste: prikimavanje, odkimavanje, zmajevanje z glavo. Prav tem v prispevku namenjam več pozornosti, saj želim izpostaviti, da je transkribiranje govorjenega pravzaprav že njegova interpretacija, torej delna analiza. Smiselno pa se mi zdi tudi členjenje pogovarjanj na dveh ravneh: na prvi ravni upoštevamo zvokovno členjenje, to je glede na intonacijski potek, smiselnost in skladnjo posameznega odse$\mathrm{ka}$, imenovanega izrek, členjenje na drugi ravni je posledica menjavanja udeležencev $\mathrm{v}$ udeleženskih vlogah. Tako dobljeno enoto imenujemo replika (angl. turn) in ne izjava. Replika je lahko motivacijska ali odzivna, obe skupaj pa tvorita temeljno gradbeno enoto pogovarjanja, to je sekvenco.
} 
v zapisanem besedilu ne ustreza povsem zvokovnemu poteku govorjenega besedila. Govorjeni jezik tvorijo z intonacijskega in semantičnega vidika zaključene enote, ki niso nujno tudi skladenjsko zaključene. Povedano drugače: intonacijski premori ne sovpadajo vedno s skladenjskimi mejami. Ker raba transkribcijskega sistema, tvorjenega na osnovi grafičnih simbolov za ločila, ne zajame načina, kako se besede in izrazi dejansko kopičijo $\mathrm{v}$ govorjenem jeziku, se pri transkripciji opuščajo velika začetnica, končna ločila, vejica itd. S premikom težišča raziskovanja na skladnjo in analizo dvogovora je tako postala vse popularnejša ortografska transkripcija, v kateri pa so izbrani deli še vedno prikazani tudi fonetično (Pusch 2006: 227). Ortografska transkripcija je lahko dopolnjena z metapodatki, dodanimi kot opombe ali kot podatki o ozadju (background information) (isto: 226). Ti podatki pomenijo pretvorbo okoliščinskega (nebesedilnega) tipa informacije v besedilni tip informacij. Udeleženci in druge sporočanjske okoliščine, zlasti prostor in čas, imajo obvestilno vrednost, saj npr. udeleženci s svojimi kretnjami, mimiko obraza sporočajo, npr. z roko je pokazala na stol in dejala: (Kar naprej), prosim. Tako je pretvorba konkretnega komunikacijskega stika v zapisano obliko interpretacija sporočenega, ki je v prvi vrsti odvisna od izhodiščnih (teoretičnih) hipotez.

2.1 Izhodiščno kot nujni minimum pri transkripciji pa npr. J. Zeman (Hoffmannová idr. 1999: 166) razume vključitev prozodičnih značilnosti, ki so del celotne zvokovne podobe govorjenega komunikacijskega stika. V prozodiji tako ločuje tri skupine pojavov: a) dinamična sredstva: intenzivnost glasu, poudarek in naglas, b) melodična/tonska sredstva: melodija/intonacija in glasovni razpon in c) kvantitativna/časovna sredstva: kvantiteta, tempo (hitrost govora), premori in ritem. V dvogovorih so prozodične značilnosti lahko hkratne, se dopolnjujejo, vzajemno stopnjujejo itd.

2.1.1 Večinoma se raziskovalci ukvarjajo $\mathrm{z}$ intonacijo in premori, manj z ritmom, intenzivnostjo in barvo glasu. Intonacija je pomembna vsaj zaradi treh funkcij, ki jih opravlja: govor členi na stavčne odseke, ${ }^{3}$ izraža sporočanjsko funkcijo izreka in izraža čustveno obarvanost izreka.

2.1.1.1 Razumevanje intonacije se je precej spreminjalo. Danes intonacija ni le razlika med zapisano povedjo in to isto povedjo, prebrano na glas (Couper-Kuhler 2001: 14), ${ }^{4}$ ampak soobstajajo vsaj tri pojmovanja intonacije: a) intonacija je del slovnice, b) intonacija je del informacijskega poteka in c) intonacija oziroma prozodija je kontekstualizacijski namig (isto: 14-18).

${ }^{3}$ Izreke lahko delimo v tonske enote, ki se nagibajo k temu, da sovpadejo s slovničnimi enotami, npr. s stavki (Komar 2002: 66).

${ }^{4}$ Tudi J. Toporišič (2000: 533-554) svoje razlage podaja na primerih branja literarnih besedil, kar naj bi predstavljalo idealno podobo stavčne intonacije slovenskega jezika. Zato, npr. S. Komer (1996) meni, da njegov opis ni opis dejanskega stanja v govorjeni slovenščini. 
2.1.1.1.1 Pojmovanje intonacije kot dela slovnice je tradicionalno. ${ }^{5}$ Najzgodnejša dela o intonaciji so iskala ujemanja med pripovedno, vprašalno in vzklično povedjo ter končno padajočo ali rastočo intonacijo. Tako naj bi se pripovedna poved $\mathrm{v}$ slovenščini končevala $\mathrm{s}$ padajočo, pripovedno intonacijo (kadenco), odločevalna vprašalna poved $\mathrm{z}$ rastočo, vprašalno intonacijo (antikadenco), dopolnjevalna vprašalna poved $\mathrm{s}$ padajočo intonacijo, vzklična poved pa $\mathrm{z}$ vzklično intonacijo, ki ima drugačno intonacijsko ogrodje kot pripovedna ali vprašalna in je lahko rastoča ali padajoča (Toporišič 2000: 550).

Pod vplivom teorije govornih dejanj je intonacija postala sredstvo kazanja ilokucijske moči izreka, zato npr. D. Schiffrin (1995: 63-70) meni, da je intonacija včasih edini namig, da gre pri izrekih za vprašanje, vendar pa včasih niti skladnja niti intonacija nista nujno niti zadostno merilo za identifikacijo vprašanja. Navedeno avtorica ponazori z zgledom Hočeš bonbon s končno rastočo intonacijo. Tu intonacija nakazuje ilokucijsko moč izrečenega, saj jo lahko povežemo s pogoji za posrečenost dvogovornega dejanja vprašanja. Končna rastoča intonacija namreč sporoča a) nepopolnost (pripravljalni pogoj), b) nezanesljivost na področjih, ki se ne nanašajo na propozicijo, npr. glede naslovnikovega razumevanja izrečenega ali glede ustreznosti prispevanega $\mathrm{k}$ dvogovoru (iskrenostni pogoj), in c) zahtevo po naslovnikovem odzivu (bistveni pogoj). Kadar tvorec sprašuje po naslovnikovih željah, potrebah, je na naslovniku, da potrdi ali zanika prisotnost teh želja, potreb, kar lahko razumemo kot prehod od razprave o tvorčevi nezanesljivosti do načinov odpravljanja te nezanesljivosti. Ko začnemo govoriti o naslovnikovi odgovornosti, da zagotovi, priskrbi tvorcu informacijo, smo od pripravljalnih pogojev prešli k bistvenemu pogoju: Hočeš bonbon? pomeni tvorčev poskus izvabiti informacijo od naslovnika. Ker je od naslovnika odvisno, da potrdi izrečeno, gre za pripravljalni in bistveni pogoj, ki sta značilna za dvogovorno dejanje vprašanje.

D. Schiffrin (Schiffrin 1994: ix) opozori tudi na pomen intonacije pri diskurznih usmerjevalcih in začetnikih. Vpliv, ki ga lahko ima posamezen izraz, je lahko odvisen od načina, kako je izrečen. Npr. aha izgovorjen s padajočo intonacijo izraža sprejem informacije, izgovorjen z rastočo intonacijo, je lahko zahteva za potrditev. Rastoča intonacija je univerzalni znak, da govorec še ni do konca dopolnil propozicije: da mu manjka njen del, naslovnikova potrditev, strinjanjem, razumevanje, naslovnikovo védenje (Schiffrin 1994: 270). ${ }^{6}$

2.1.1.1.2 Intonacija kot del informacijskega poteka je povezana $z$ gibanjem idej $\mathrm{v}$ stanje aktivne, deloma aktivne in neaktivne zavesti in iz teh stanj zavesti (Couper-Kuhler 2001: 15). Intonacija naj bi nudila okno v zavest $\mathrm{z}$ osnovanjem dveh različnih tipov enot: intonacijske in poudarjene enote. Intonacijska enota vsebuje informacije, ki jih ima govorec trenutno v mislih; poudarjena enota pa omogoča aktiviranje novega ter aktiviranje možne in/ali dane informacije.

${ }^{5}$ Značilno je umeščanje intonacije med parajezikovna sredstva, npr. Korošec 1998, Zadravec Pešec 2000.

${ }^{6}$ Glej dalje zgled $m h m h m$. 
Tak je na primer Hallidayev pristop (Halliday 1998: 292-308) k pojmovanju intonacije oz. tonskega poteka, ki je predmet avtorjevih raziskav poleg ritma in tona. Za Hallidaya je tonska, intonacijska enota realizacija informacijske enote v dvogovoru. Ta enota ne sovpade natančno s katero koli drugo slovnično enoto, npr. s stavkom, saj je lahko stavek deljen v dve ali več informacijskih enot; ali ena sama informacijska enota v dva stavka ali več stavkov. Informacijska enota je del informacijskega sistema in pomeni napetost med znanim ali napovedljivim in novim ali nenapovedljivim. Tako je informacijska enota sestavljena iz dveh delov: danega in novega. Ker je dano pogosto redudantno, je to fakultativni del informacijske enote, novo pa obvezni. Element tonske enote, ki nosi glavni poudarek, je informacijsko žarišče. Če se informacijsko žarišče pojavi pred danim, govorimo o zaznamovanem informacijskem žarišču. Intonacijski vzorci izražajo informacijsko strukturiranje izrečenega, saj je velik del informacijske strukture jezikovno izražen z intonacijo. Tako leksikalni pomen besed in njihova skladenjska zgradba uvezeta običajni pomen povedi, medtem ko intonacija zagotavlja različne funkcije, ki so predstavljene na ločenih nivojih (izrek). $\mathrm{Z}$ drugimi besedami: intonacija je nad skladnjo, informacija je nad semantiko (Heusinger 1999: 3-4).

Za določanje smisla izrečenega je pomemben tudi ton. Tonski sistem je po Hallidayju (Halliday 1994: 292-308) osnovan na opoziciji rastoče-padajoče. Padajoči ton izraža zanesljivost, rastoči pa nepopolnost, negotovost. Toni imajo dominantno in recesivno sporočilno vrednost, ki je veljavna za vse položaje, v katerih se ton lahko pojavi. Tako tudi v slovenščini velja, da padajoči toni informirajo, rastoči pa sklicujejo. Tvorec informacijam, ki so že del skupnega védenja, dodeli rastoči ton, če pa se mu zdi, da bi jih bilo treba zaradi jasnosti sporočila posebej poudariti, jim dodeli informativni ton. Rastoči ton ima poleg sklicevalne funkcije tudi pojasnjevalno. Rastoče-padajoči ton je poudarjena oblika (dominantna) padajočega tona. Ne izraža presenečenja, ampak nasprotno mnenje, včasih tudi kljubovalnosti. Kot navaja S. Komar (1996: 42-52, 134-163), ta ton rabimo za poudarjanje nemogočega ali težko spremenljivega splošnega dejstva, za poudarjanje informacij, ki so v nasprotju s pričakovanji, ali pa so del skupnega védenja, a so zaradi želje po izogibanju nesporazumov izpostavljene.

2.1.1.1.3 Pojmovanje intonacije kot kontekstualizacijskega namiga za priklicevanje določenega interpretativnega okvira izrečenega dopolnjuje spoznanja o intonaciji kot delu informacijskega poteka (Couper-Kuhler 2001: 16-17). Intonacijo je kot vse druge jezikovne znake treba vključiti v konkretne sporočanjske okoliščine, da bi izrečeno lahko interpretirali v celoti. ${ }^{7}$ Sporočanjske okoliščine so torej priklicane s pomočjo konteksualizacijskih namigov oziroma konteksualizacijski namigi naredijo okoliščine relevantne za interpretacijo v določnem okviru. Intonacija kot konteksualizacijski namig redko nastopa sama, saj isti interpretativni okvir lahko prikličemo tudi s tempom ali intenzivnostjo

\footnotetext{
${ }^{7}$ V tem smislu so vsi jezikovni znaki deiktiki (Couper-Kuhler 2001: 16).
} 
glasu, torej z več načini hkrati. Te načine običajno imenujemo prozodija. Tako ne gre pravzaprav le za pojmovanje intonacije, ampak prozodije kot kontekstualizacijskega namiga. Prozodični fenomeni niso slučajni ali naključni, niti niso razumljeni kot samodejni odziv spoznavnih in čustvenih stanj, ampak naj bi imeli svojo sistemskost, dostopno le v konkretnih komunikacijskih stikih. S tega vidika lahko prozodične fenomene razumemo kot oporo npr. pri vzorcih prevzemanja replik. Ti vzorci pomagajo udeležencem pri srečevanju z dvema glavnima vrstama zahtev: sistemskih in ritualnih. Sistemske zahteve so zahteve, ki jih interakcija mora imeti, saj imata udeleženca določene anatomske, fizikalne in tvorbene sposobnosti. Ritualne zahteve pa vključujejo pravila, ki vladajo interakciji, izhajajoč iz tega, da sta udeleženca osebi, ki jima vladajo norme dobrega ali primernega vodenja postopka. Tako prozodični kontekstualizacijski namigi pomagajo prirazumljati udeležencem po eni strani o možnih prevzemih replik, o urejanju tega, kdo bo govoril, po drugi strani pa o tem, katera dejanja so bila izvedena in katere dejavnosti so bile izvedene, kako se bodo nadaljevale in kako lahko njihov razvoj vpliva na potek komunikacijskega stika.

2.1.1.2 Čeprav so intonacija in drugi prozodični fenomeni zelo pomembni, je njihov popis nejasen, nenatančen (Hoffmannová idr. 1999: 166-167). Brez prave metodologije ne moremo pričakovati pravih rezultatov, po drugi strani pa različni nameni raziskav zahtevajo različne transkripcije.

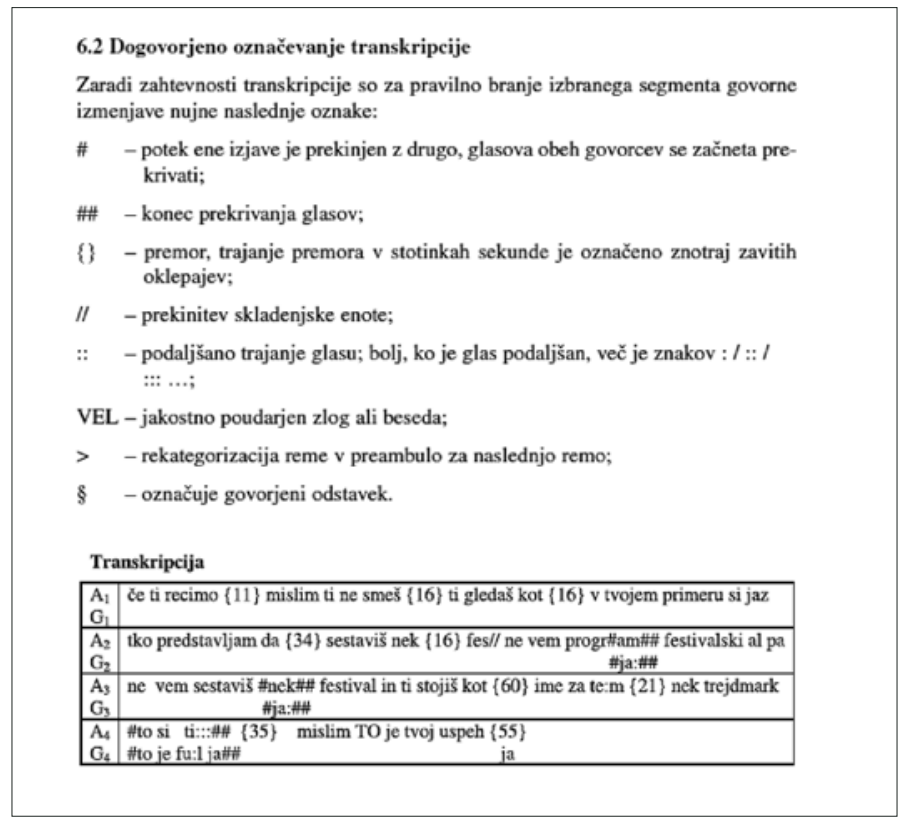

Slika 1: Vir: Vitez 2004: 14. 
Neenotnost pri transkribiranju govorjenih komunikacijskih stikov ponazarjajo načini transkribiranja, kot jih predlagajo npr. P. in A. Vitez (slika 1) in S. Komar (slika 2) ter mednarodno uveljavljen pristop $\mathrm{k}$ analizi diskurza, konverzacijska analiza (v nadaljevanju CA).

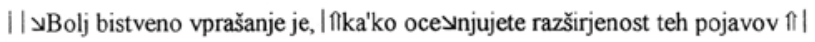
kođrupcije, $\Downarrow \mid$ kođrupcijskega ravnanja $\Downarrow \mid \Downarrow$ 'prej ste govorili tudi o reviðzijskih hišah. I (D/4/17-19)

Legenda:

|| - označuje konec povedi, | - označuje konec tonske enote znotraj povedi.

$\downarrow$ - padajoči ton, $\uparrow$ - rastoči ton, $\uparrow \downarrow$ - visoki oz. nizki tonski zaključek.

Slika 2: Vir: Komar 1996: 149.

2.1.1.2.1 Raziskovanje v okviru konverzacijske analize ${ }^{8}$ se začne z zvočnim in/ali video snemanjem naravno pojavljajočih se pogovarjanj. ${ }^{9}$

\begin{tabular}{|c|c|c|}
\hline Angleško & & Slovensko \\
\hline $\begin{array}{l}\text { - word } \\
\text { - wor:d } \\
\text { - sto- } \\
\text { - > faster< } \\
\text { - <slower> } \\
\text { - LOud } \\
\text { - } \text { 'soft }^{\circ}\end{array}$ & $\begin{array}{l}\text { The length of silences between and } \\
\text { within turns is measured in tenths of } \\
\text { seconds. } \\
\text { A dot between brackets (.) indicates a } \\
\text { short silence of less than } 0.2 \text { seconds. } \\
\text { In the case of simultaneous talk, the } \\
\text { onset of the overlapping turn is located } \\
\text { by a left square bracket in the over- } \\
\text { lapped turn. } \\
\text { A period indicates a falling final pitch } \\
\text { contour, a comma a slightly rising } \\
\text { pitch contour, and a question mark a } \\
\text { strongly rising one. } \\
\text { Vertical arrows provide information } \\
\text { about local pitch movements within } \\
\text { syllables or at the level of a single syl- } \\
\text { lable. A downvard arrow signals a } \\
\text { falling tone movement, an upward } \\
\text { arrow a rising one. } \\
\text { Underlining signals salient stress. } \\
\text { A colon renders a noticeable sound } \\
\text { stretch. } \\
\text { The hyphen is used as a cut-off marker. } \\
\text { This utterance part is produced with } \\
\text { higher pace than the talk surrounding } \\
\text { it. } \\
\text { The pace is relatively slower. } \\
\text { Capitals indicate relative loudness. } \\
\text { The degree sign signals that an utter- } \\
\text { ance part is produced more softly than } \\
\text { the surrounding talk. } \\
\text { Hearable inbreath. } \\
\text { Hearable aspiration. } \\
\text { The transcriber is uncertain about the } \\
\text { utterance part between parentheses. }\end{array}$ & $\begin{array}{l}\text { - . , ? - pika označuje padajoči končni ton (torej končno } \\
\text { padajočo intonacijo), vejica rahlo rastočo linijo } \\
\text { (intonacijo), vprašaj pa močno rastočo. } \\
\text { - Navpična puščic označuje informacijo o trenutnim } \\
\text { tonskim potekom znotraj zloga ali na ravni } \\
\text { posameznega zloga (splošna lastnost simbola, puščice). } \\
\text { Puščica navzdol padajoči tonski potek, puščica } \\
\text { navzgor pa rastočega. } \\
\text { - Podčrtano označuje očiten poudarek. } \\
\text { - Dvopičje prikazuje opazno glaovno napetost. } \\
\text { - Vezaj označuje prekinitev. } \\
\text { - Del izreka je izgovorjen hitreje kot obdajajoči deli } \\
\text { (tempo). } \\
\text { - Del izreka je izgovorjen počasneje kot obdajajoči deli. } \\
\text { - Velike črke označujejo relativno glasnost. } \\
\text { - Del izreka je izgovorjen bolj nežno kot obdajajoči deli. } \\
\text { - Slišen vdih. } \\
\text { - Slišen izdih. }\end{array}$ \\
\hline
\end{tabular}

Slika 3: Legenda, kot jo predlaga konverzacijska analiza. Vir: Mazeland 2006: 154.

${ }^{8}$ Povzeto po Mazeland 2006: 153-154.

${ }^{9}$ P. in A. Vitez (2004) v svojem prispevku analizirata spodbujen ožjeinteresni dvogovor, S. Komar (1996) pa analizira širšeinteresnega. 
Ti posnetki so transkribirani tako, da prikazujejo podrobnosti, ki prispevajo $\mathrm{k}$ organizaciji in razumljivosti pogovarjanja. Zapisujejo se podatki o prozodiji in razporeditvi replik. Zaradi dodatnih posnetkov imajo raziskovalci možnost analizirati jezikovno rabo v okoliščinah, kot so jih imeli na voljo udeleženci pogovarjanj..$^{10}$

CA-transkripcija je berljiva brez posebnega predznanja (slika 3). Zapis ne predstavlja produkcije govora na ravni mehanične poustvaritve, saj naj bi transkripcija kot rezultat prepletanja skrbnega poslušanja, kje in kako so bili izreki tvorjeni, in interpretativnega dela zapisovalca kot kompetentnega člana opazovane kulture nudila empirično zanesljive približke dogajanj, s katerimi so razpolagali tudi udeleženci komunikacijskega stika.

2.1.1.2.2 Kako torej transkribirati npr. zgled 1, da bo zapis kar natančneje odražal smisel sporočenega? V pomoč so lahko računalniški programi, kot sta Cool Edit in Praat (slika 4).

\section{Zgled 1}

$\mathrm{mh} \mathrm{mh} \mathrm{mh} \breve{c} e$ ni to to pol ni to to ampak je to to

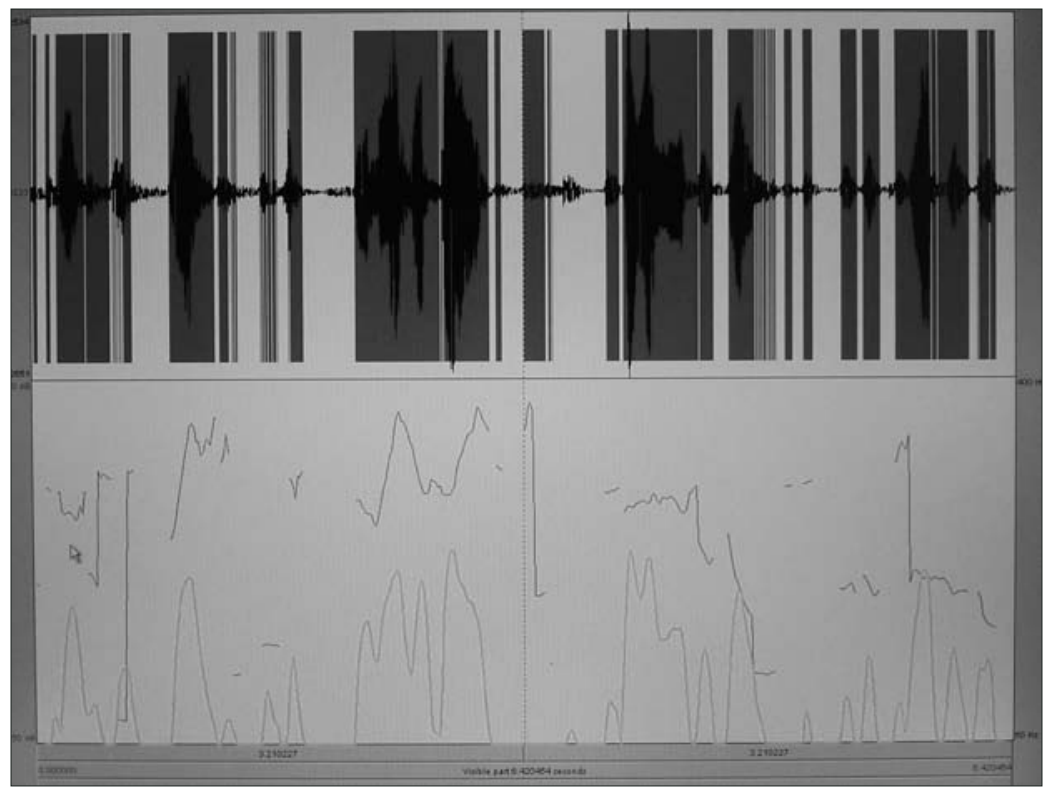

Slika 4: $\mathrm{mh} \mathrm{mh} \mathrm{mh}$ če ni to to pol ni to to ampak je to to.

2.1.1.2.2.1 Kako zapisati, kar računalniški program prikaže grafično (sliki 5 in 6)? Obstajata dva temeljna tipa zapisa: linearni in notni. Pri prvem so replike

${ }^{10}$ Zgoščenka s posnetki dvogovorov je zato pogost dodatek knjigam. 
posameznih govorec zapisane kot $\mathrm{v}$ scenariju za (gledališko) igro. Ta zapis je manj zapleten in zato primeren za uporabo $\mathrm{v}$ korpusne namene.

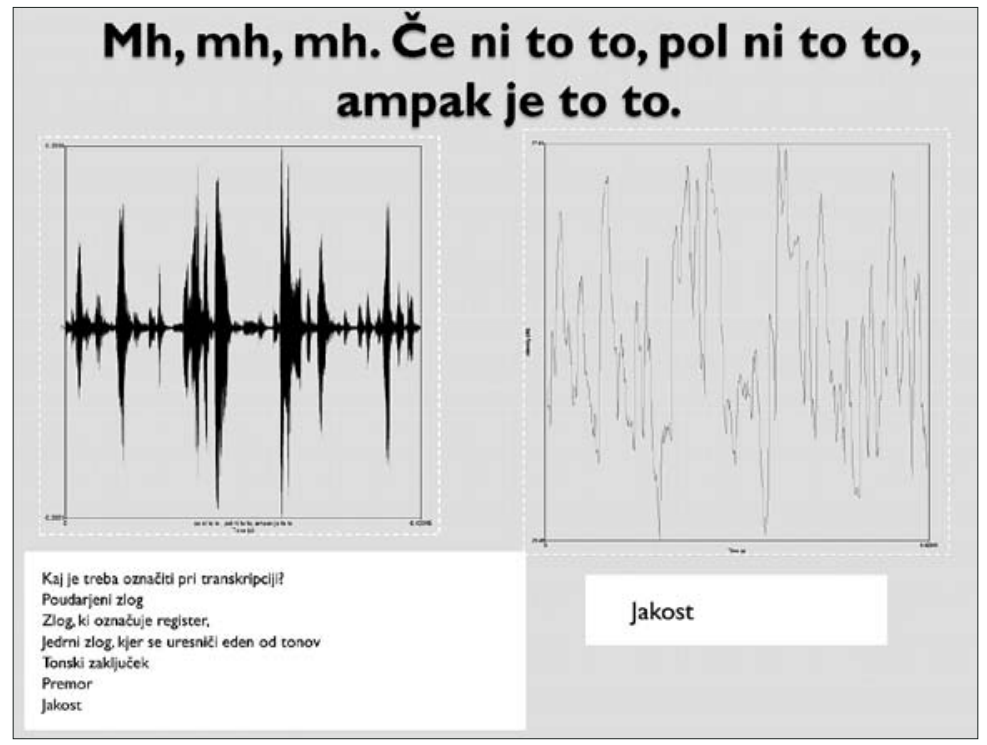

Slika 5: Računalniški program Praat prikazuje jakost izrečenega $\mathrm{v}$ izbranem analiziranem segmentu.

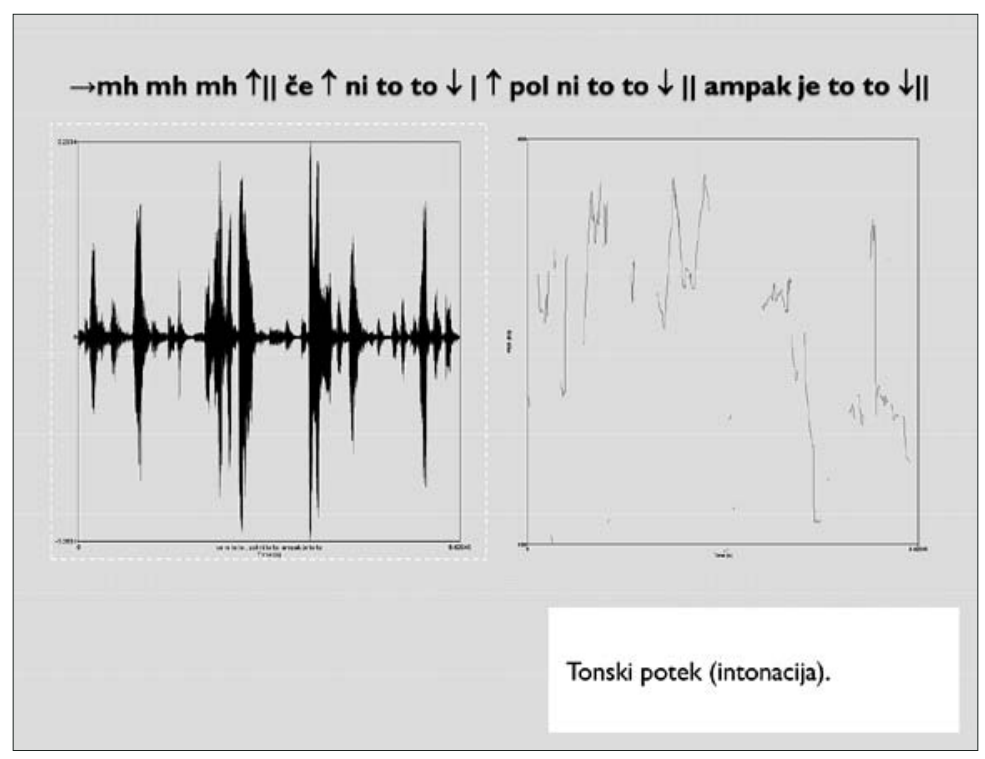

Slika 6: Računalniški progam Praat prikazuje intonacijo izrečenega v izbranem analiziranem segmentu. 
Pri drugem, notnem zapisu so replike različnih udeležencev komunikacijskega stika razporejene vertikalno glede na čas. Ta zapis omogoča učinkovito predstavitev tistih delov pogovarjanj, ki kažejo na borbo za besedo, prekrivanje in govorjenje hkrati. Poleg navedenih tipov zapisa naj omenim še t. i. medlinearno tonično transkripcijo. To je transkripcija $\mathrm{v}$ dveh ali treh vrsticah, rabljena za predstavitev vrha in dna govorčeve naravne tonske višine. R. de Beaugrande (Beaugrande 2006) pa meni, da je najnatančnejši vendarle grafični prikaz (slika 7).

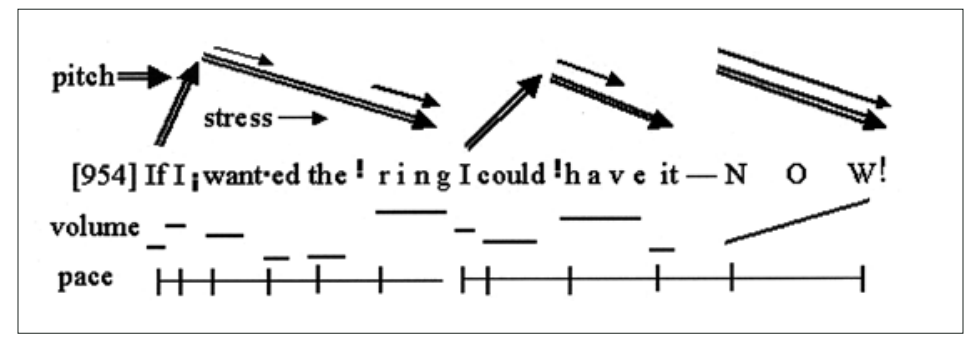

Slika 7: Grafični prikaz po de Beaugrandu (2006); pitch - ton, stress - poudarek, volume - jakost, pace - ritem, tempo.

2.1.1.3 A branje zapisa ne more pojasniti storjenega z izrekanjem zapisanega, saj bi to pomenilo, da je lahko s preprostim nizom besed nek dvogovor zvesto prikazan (Ducrot 1988: 134). ${ }^{11}$ Analizo in popis prozodije dvogovora je treba delati v razmerju z drugimi jezikovnimi, s parajezikovnimi in z nejezikovnimi sredstvi. Tu bi se ustavili le ob analizi prozodičnih značilnosti dvogovora $\mathrm{v}$ razmerju s parajezikovnimi in z nejezikovnimi sredstvi, saj ta pomensko sodelujejo pri oblikovanju smisla izrečenega, torej tvorijo sporočilo v smislu, da imata udeleženca, postavljena $v$ konkreten sporočanjski prostor in čas, določeno obvestilno vrednost. Parajezikovna in nejezikovna sredstva, npr. smeh, hrup, geste (gibi rok), mimika (gibi čela, nosu, oči, obrvi), položaj telesa in njihovo medsebojno razmerje pri posameznem človeku (male relacije) in med ljudmi (velike relacije), je nujno treba vključiti v zapis, ne le kot sprotne ali končne opombe (Pusch 2006: 228)..$^{12} \mathrm{Na}$ pomen očesnega stika v svoji razpravi » Řeč

${ }^{11}$ Ducrot (1988: 134) za ponazoritev navaja zgled Dovolim ti, da greš v kino, ki lahko pomeni Ne bom te kaznoval / ne bom ti štel kot napačno, če dejanje izvršiš ali Omogočil ti bom / ne bom te oviral, da dejanje izvršišs, saj meni, da ne obstaja filološki argument, ki bi utemeljil odločitev, kateri smisel je verjetnejši od drugega. V takih primerih je verjetno smiselno govoriti o večfunkcijskosti izreka, ki omogoča različne odzive na izrečeno (Schiffirn 1995: 62).

${ }^{12}$ Ko se pogovarjanje konča, udeleženca seboj ne odneseta transkripcije. Predvidevamo pa, da se spremenita: naučila sta se stvari o soudeležencu, svetu na sploh, lahko sta se dogovorila in dosegla cilje itd. Četudi je vsaka izgovorjena beseda pozabljena, je bilo nekaj doseženo, ampak ta dosežek ni izdelava predmeta: večina transkripcij pogovarjanj, kot jih preučujejo jezikoslovci ali npr. sociologi, se udeležencem zdi bizarna. To dejstvo je treba upoštevati pri proučevanju transkripcije (Owen 1990: 253). 
oči $v$ konverzační analýze a interakční sociolingvistice opozori J. Hoffmannová (1999: 84-90). Avtorica povezuje pomen pogleda v odvisnosti od udeleženčevega (ne)prizadevanja pri prevzemanju replike. Če si udeleženec repliko želi pridobiti, v trenutnega govorečega upira pogled s pomenom Hočem govoriti. Če nagovarja soudeležence, potem vanje upira pogled s pomenom Poslušajte me, Sledite mi. Če želi repliko dodeliti dalje, potem izbere naslednjega govorca tako, da nanj pokaže ali ga ogovori in vanj upira pogled s pomenom Prevzemi repliko. Če želi repliko obdržati, potem svoj pogled s pomenom Hočem govoriti dalje usmerja v nedoločenega, neizbranega naslovnika. Če udeleženec ne želi prevzeti replike, potem gleda proč, $v$ tla, trenutnemu govorečemu pa izmika pogled v pomenu Ne želim govoriti. Če udeleženec ne želi biti ogovorjen, lahko izmika pogled v pomenu Ne želim te poslušati (Hoffmannová 1999: 89-90). Tudi smeh kot zvočni pojav človekovih čustev, s katerim artikuliramo izrek in ga modificiramo, komentiramo vsebino izrečenega, omilimo izrečeno ali skušamo prekriti ost ali pa komentiramo soudeleženčevo sporočilo (Krajnc Ivič 2009: 39), kaže na součinkovanje jezikovne in nejezikovne dejavnosti. To součinkovanje se pojavlja na dva načina: a) nejezikovna dejavnost podpira jezikovno dejavnost $\mathrm{k}$ določeni možni interpretaciji in b) nejezikovna dejavnost prisoja jezikovni različne smisle (Hoffmannová idr. 1999: 169-170). Za zgled vzemimo gostiteljev sprejem gosta. Kot 'vesel sprejem' razumemo prozodične značilnosti in leksikalno-skladenjsko zgradbo, ki ju lahko povežemo z nejezikovnimi dejavnostmi: gostitelj A gleda gosta B v oči, se mu nasmeje, da gostu prednost pri vratih, s kretnjo mu pokaže, kam naj sede itd. Tako jezikovna kot nejezikovna dejavnost potekata počasi. Lahko pa začetni sprejem [2], ki na ravni leksikalno-skladenjske zgradbe kaže na vesel, prijazen sprejem, prav na ravni nejezikovne dejavnosti in prozodičnih značilnosti najprej nakaže, da sta prijaznost, veselost udeležencev komunikacijskega stika ob sprejemu le navidezna. Pri neprijaznem sprejemu se gostitelj A ne nasmehne, če pogleda gosta v oči, je njegov pogled drugačen, kot če gre za prijazen sprejem. Tudi tu je torej nejezikovna dejavnost skladna z jezikovno, a je ta hitrejša kot pri prijaznem sprejemu (Hoffmannová idr. 1999: 178).

\section{Zgled 2}

$\mathrm{R}_{3}$ : Kako si?

$\mathrm{J}_{5}$ : Odlično! Odlično. Evo.

$\mathrm{R}_{4}$ : Lepo slišat.

$\mathrm{J}_{6}: \mathrm{Ja}$.

$\mathrm{R}_{5}$ : Sn te povabu, da slišim, kako, kaj, zakaj - mislim, če kaj trpiš res tolk, ne, ker men pač za pet milijonov tožeš zarad [psi]hičnih bolečin in to in sn prišo pogledat, kako si, ne. Sem

$\mathrm{J}_{7}$ :

$\mathrm{R}_{5}$ : vesel, $\mathrm{k}$ rečeš, da si $\mathrm{v}$ redu, ne.

$\mathrm{J}_{8}$ : Jah. Trpel sm. Seveda sem trpel. Moji so trpel. 
2.1.1.3.1 Smisel sporočenega je $v$ neposrednih komunikacijskih stikih dosežen ne le s prepletanjem jezikovne in nejezikovne dejavnosti [3], ampak s smiselno pritegnitvijo zunanjih sporočanjskih okoliščin, ko npr. govorec svoje misli ne izreče do konca - govorimo o zamolku kot nedokončani skladenjski zgradbi (Krajnc Ivič 2005: 62) - smisel sporočenega pa nakaže nejezikovno [4], zato so pomembne vse informacije o sporočanjskih okoliščinah konkretnega komunikacijskega stika. Vrednotenje izbranega dela dvogovora zaradi nedokončane skladenjske zgradbe kot nesoveznega ni ustrezno in ne prinaša realnih ugotovitev.

\section{Zgled 3}

$\mathrm{I}_{5}$ : A saharco ješ?

$\mathrm{J}_{6}:$ Mh, ne, z dvojno čokolado.

$\mathrm{I}_{6}$ : Aha.

$\mathrm{J}_{7}$ : Boš ti | tudi?

$\mathrm{I}_{7}$ : Nənə.

$\mathrm{J}_{8}$ : Hujšaš (z roko se nežno dotakne sogovorkinega nosečniškega trebuha).

$\mathrm{I}_{8}$ : Ha ha ha! Nesramen.

Za zgled [4] je tako treba vedeti, da je analizirana pasaža del pogovora med Zmagom Jelinčičem Plemenitim in Vitom Rožejem, ${ }^{13}$ da je bil pogovor posnet in predvajan v nekdanji stalni rubriki Klepet ob kavi oddaje Dobro jutro na nacionalni televizijski postaji, ${ }^{14}$ da je scenarij za to rubriko predvideval, da se zaprosi znano osebo, da na klepet povabi drugo kar najširši javnosti znano osebo. Če povabljenec s pomočjo sedmih vprašanj ugotovi identiteto gostitelja, gostitelj plača zapitek, sicer povabljenec. Tako je Vito Rožej povabil Zmaga Jelinčiča, ki pa identitete gostitelja ni ugotovil, zato na določeni točki Jelinčič zaključi pogovor s pozivom natakarju, da želi poravnati zapitek. ${ }^{15}$

\section{Zgled 4}

$\mathrm{J}_{20}$ : A hm, ne vem. Gospod Peče je ... Če mogoče mediji ne razumete tega, ampak gospod Peče je drug človək.

$\mathrm{R}_{20}: \mathrm{Ja}$ ?

$\mathrm{J}_{21}$ : To nisem jest. No, torej vsak ima pravico do svojega razmisleka, ne?

$\mathrm{R}_{21}$ : Ta podobnost je, ne.

$\mathrm{J}_{22}$ : A lahko plačam, prosm $\rightarrow$.

$\mathrm{R}_{22}$ : Hvala za kavo.

$\mathrm{J}_{23}$ : Prosim. Namreč a ... (Proti kameri pokaže listek z imenom osebe, za katero je govorec napačno predvideval, da ga je povabila na kavo.)

${ }^{13}$ Tudi zgled 2 je pasaža tega pogovora.

${ }^{14}$ Tudi zgled 3 je transkripcija Klepeta ob kavi.

${ }^{15}$ Korpusi govorjenega jezika običajno predstavljajo javne, torej širši publiki namenjene monologe, dialoge, posredovane preko radijskih postaj. Tako dobljeni podatki ne predstavljajo povsem spontanih komunikacijskih stikov, ampak so do določene mere simulirani, igrani, spodbujeni (Pusch 2006: 227). Učinek tega na samo komuniciranje je odvisen od veščosti govornega nastopanja udeležencev. 
3 Natančnost transkripcije dvogovora v zapisano obliko kot pretvorbo tudi okoliščinskega (nebesedilnega) tipa informacije v besedilni tip informacij je v prvi vrsti odvisna od teoretičnih izhodišč in od ciljev, ki naj bi jih prikazovalo transkribirano in interpretirano gradivo. Mini diski, digitalni snemalniki, telefoni in drugi pripomočki za snemanje sicer omogočajo diskretno, neopazno snemanje spontanih, neigranih vrst neposrednih ožjeinteresnih komunikacijskih stikov in s tem preprečujejo vpliv Labovega opazovalnega paradoksa, a je tako zbrano gradivo zaradi etičnih pomislekov in zakonskih omejitev neuporabno. Zato je seveda toliko večja želja in potreba po popolni transkripciji z ustreznimi dovoljenji pridobljenih (avdio-video) posnetkov. Taka transkripcija bi bila verjetno težko zapisljiva in berljiva, a bi omogočila večkratno uporabo že zbranega gradiva. S tega vidika se kot zelo zanimiva možnost ponujajo telefonski dvogovori, saj praviloma sodelujeta le dva udeleženca, ki lahko neposredne sporočanjske okoliščine izkoriščata v manjši meri, zato je v takih dvogovorih manj govorjenja hkrati, ostenzivnih deiktikov in nedokončanih skladenjskih zgradb kot posledic nejezikovne realizacije sicer verjetnejše jezikovne dejavnosti.

\section{LITERATURA}

Elizabeth COUPER-KUHLER, 2001: Intonation and discourse: Current views from within. The handbook of discourse analysis. Ur. Deborah Schiffrin, Deborah Tannen, Heidi E. Hamilton. Oxford: Blackwell. 13-34.

Teun A. Van DIJK, 2002: Political discourse and political cognition. Politics as Text and Talk. Analytical approaches to political discourse. Ur. Paul A. CHILTON, Christina SCHÄFFNER. Amsterdam: Benjamins. 203-237.

Oswald DUCROT, 1988: Izrekanje in izrečeno. Ljubljana.

Jane A. EDWARDS, 2001: The Transcription of discourse. The handbook of discourse analysis. Ur. Deborah Schiffrin, Deborah Tannen, Heidi E. Hamilton. Oxford: Blackwell. 321-348.

Michael Alexander Kirkwood HALLIDAY, 1998: An Introduction To Functional Grammar. 6th impression. London. 292-308.

Klaus von HEUSINGER, 1999: Intonation and Informaction structure. Habilitationsschirft. Facultiy of Philosophy. University of Konstanz.

Jana HOFFMANNOVÁ, 1999: »Řeč oči« v konverzační analýze a interakční sociolingvistice. V J. Hoffmannová, O. Müllerová: Dialog v češtině. München. 84-90.

Jana HOFFMANNOVÁ, Olga MÜLLEROVÁ, Jiř́i ZEMAN, 1999: Konverzace v češtině. Přri rodinných a práteských návštěvách. 1. vyd., Praga: Trizonia.

Smiljana KOMAR, 1996: Funkcija intonacije v diskurzivni analizi intervjuja $v$ angleščini in slovenščini. Doktorska disertacija. Ljubljana.

,-- 2002 : The communicative values of key and termination in slovene. Govor XIX 1, 65-77. 
Mira KRAJNC IVIČ, 2005: Besedilne značilnosti javne govorjene besede. Maribor: Slavistično društvo Maribor. (Zora 35.)

--, 2009: Razgovor kot vrsta komunikacijskega stika. Maribor: Mednarodna založba Oddelka za slovanske jezike in književnosti, Filozofska fakulteta. (Mednarodna knjižna zbirka Zora, 63.)

H. MAZELAND, 2006: Conversation Analysis. Encyclopedia of Language \& Lingustics. Second edition. Vol 3. Amsterdam [etc.]: Elsevier. 153-163.

Olga MÜLLEROVÁ, 1979: Komunikativní složky výstavby dialogichého textu. Praga.

Marion OWEN, 1990: Language as a spoken medium: conversation and interaction. An Encyclopeadia of Language. Ur. N. E. Collinge. Routledge, London New York. 244-253.

C. D. PUSCH, 2006: Corpora of Spoken discourse. Encyclopedia of Language \& Lingustics. Second edition Vol. 3. Amsterdam [etc.]: Elsevier. 226-230.

Deborah SCHIFFRIN, 1994: Discourse markers. Cambridge, New York, Oakleigh: Cambridge University Press.

- -, 1995: Approaches to discourse. Oxford (UK), Cambridge (USA): Blackwell.

Michael STUBBS, 1983: Discourse Analysis. The Sociolinguistic Analysis of Natural Languarge. Oxford.

Jože TOPORIŠIČ, 2000: Slovenska slovnica. Založba Obzorja, Maribor. 533-554.

Primož VITEZ, Ana ZWITTER VITEZ, 2004: Problem prozodične analize spontanega govora. Jezik in slovstvo 49/6. 3-24.

Jana ZEMLJARIČ MIKLAVČIČ 2008: Govorni korpusi. Ljubljana. Znanstvena založba Filozofske fakultete, Oddelek za prevodoslovje. Zbirka Prevodoslovje in uporabno jezikoslovje.

Renata ZADRAVEC PEŠEC 2000: Besedilotvorni vidiki navezovanja v slovenskih neumetnostnih besedilih. Doktorska disertacija. Ljubljana.

\section{SPLETNI VIR}

Robert A. de BEAUGRANDE, 2006: Prosody in the Study of Text and Discourse. http://www.beaugrande.com/UPLOADGRAMMAR\%20SIX\%20NUMBER\%20 ONE\%20NEWER.htm 


\section{HOW PRECISE CAN A TRANSCRIPTION BE?}

The transcription of a dialogue or spoken discourse into written form means transforming contextual (non-linguistic type) of information into textual. Participants and context, particularly space and time, have important influence on meaning of the concrete utterance. So transcription is actually an interpretation of a concrete discourse. Taking sensibility and usefulness of an absolute transcription into account it shows that conversational complexity caused by false starts, hesitations, self-corrections and so on is not evident to the participants themselves, but it is evident only in written form, in transcription. Evaluating discourse from coherence and cohesion point of view because of conversational complexity as incoherent and/or non-cohesive is neither appropriate nor it gives real conclusion. So the transcription should not include too much date, because the understanding is a process of selecting patterns, in which a lot of phonetic details are not important. But we should learn to observe behaviour, which during the conversation we take for granted. The transcription is never theory-neutral, so there is more than one correct transcription of an utterance. 